\title{
Poemas de William Carlos Williams
}

\author{
Tradução: José Paulo Paes
}

\author{
As traduções a seguir fazem parte dos Poemas de William Carlos Williams, \\ recentemente publicados pela Companhia das Letras. Os textos foram \\ selecionados e traduzidos por Jose Paulo Paes, que os fez preceder de um estudo \\ crítico completado durante sua estada, como professor-visitante, no Instituto \\ de Estudos Avançados da USP. Ali póde valer-se das facilidades de consulta \\ a bibliotecas do campus postas à sua disposição e teve ensejo de discutir \\ problemas de tradução com os profs. Francis H. Aubert, Martha \\ Steinberg e Paulo Vizioli.
}

\section{CONSAGRAÇÃO DE UM PEDAÇO DE TERRA}

Este pedaço de terra defronte às águas do estreito é consagrado à presença viva de Emily Dickinson Wellcome que nasceu na Inglaterra, se casou, perdeu o marido e com seu filho de cinco anos veio para Nova York num navio de dois mastros, foi bater nos Açores;

vogou a esmo até o baixio de Fire Island, encontrou o segundo marido numa pensão do Brooklyn, foi com ele para Porto Rico deu à luz mais três filhos, perdeu seu segundo marido, teve oito anos de vida dura em St. Thomas, Porto Rico, São Domingos, acompanhou o filho mais velho a Nova York, perdeu sua filha, o seu "bebe", pegou os dois meninos do segundo casamento do filho mais velho serviu-lhes de mãe - deles que eram orfăos de mãe - lutou por eles contra a outra avo e as tias, trouxe-os para cá verão após verão se defendeu aqui contra ladrões, tempestades, sol, incendio, contra moscas, moças que vinham farejar à volta, contra seca, ervas daninhas, marés de borrasca, vizinhos, doninhas que the roubavam o galinheiro, contra a fraqueza de suas proprias mãos, contra a força crescente dos meninos, contra ventos, contra pedras, contra os invasores, contra impostos, contra o seu proprio entendimento.

\section{DEDICATION FOR A PLOT OF GROUND}

This plot of ground

facing the waters of this inlet is dedicated to the living presence of Emily Dickinson Wellcome who was borm in England, married, lost her husband and with her five year old son sailed for New York in a two-master, was driven to the Azores; ran adrift on Fire Island shoal, met her second husband in a Brooklyn boarding house, went with him to Puerto Rico bore three more children lost her second husband, lived hard for eight years in St. Thomas, Puerto Rico, San Domingo, followed the oldest son to New York, lost her daughter, lost her "baby", seized the two boys of the oldest son by the second marriage mothered them - they being motherless - fought for them against the other grandmother and the aunts, brought them here summer after summer, defended herself here against thieves, storms, sun, fire, against flies, against güls that came smelling about, against drought, against weeds, storm-tides, neighbors, weasels that stole her chickens, against the weakness of her own hands, against the growing strength of the boys, against wind, against the stones, against trespassers, against rents, against her own mind. 
Cavoucou esta terra com suas proprias mãos, reinou sobre esta leira de relva, imprecou of filho mais velho até que ele a comprasse, viveu aqui quinze anos, alcançou a solidão definitiva $e-$

Se não puderes trazer a este lugar mais do que a tua carcaça, fica longe dele.

\section{O VASO DE FLORES}

Rosa confundido ao branco

flores e flores reversas

recolhem e derramam a flama velada

atirando-a de volta

à cornucopia da lâmpada

pétalas obscurecidas de través com malva

vermelho onde em volutas

cada pétala pōe seu fulgor sobre outra pétala

à volta de gargantas flamiverdes

pétalas radiantes de luz transverberada

pelejando

as folhas

$$
\text { no alto }
$$

estirando o seu verde acanhado

para fora da borda do vaso

e eis ali o vaso, de todo obscuro garrido em sua capa de musgo.
She grubbed this earth with her own hands, domineered over this grass plot, blackguarded her oldest son into buying it, lived here fifteen years, attained a final loneliness and -

If you can bring nothing to this place but your carcass, keep out.

\section{THE POT OF FLOWERS}

Pink confused with white flowers and flowers reversed take and spill the shaded flame darting it back into the lamp's horn

petals aslant darkened with mauve

red where in whorls. petal lays its glow upon petal round flamegreen throats

petals radiant with transpiercing light contending

the leaves

$$
\text { above }
$$

reaching up their modest green from the pot's rim

and there, wholly dark, the pot gay with rough moss. 
Transitando com a ıdéra posta em nada deste mundo

a não ser o direlto de passagem eu desfruto a estrada por

eferto de le1 -

vi

um homem de idade

que sorriu e desviou o olhar

para o norte, além de uma casa uma mulher de azul

que estava rindo e se inclinando para a frente

a fim de olhar o rosto meio

voltado do homem

e um menino de uns oito anos que olhava para o meio da

barriga do homem

para uma corrente de relógı -

A suprema importância

deste inominado espetáculo

fez com que eu acelerasse

ao passar por eles sem palavra -

Por que me importaria o rumo?

e lá fui rodando sobre as

quatro rodas do meu carro

pela estrada molhada até

que vi uma moça com uma perna sobre o parapeito de um balcão.
In passing with my mind

on nothing in the world

but the right of way

I enjoy on the road by

virtue of the law -

I saw

an elderly man who

smiled and looked away

to the north past a house a woman in blue

who was laughing and

leaning forward to look up

into the man's half

averted face

and a boy of elght who was looking at the middle of

the man's belly

at a watchchain -

The supreme importance

of this nameless spectacle

sped me by them

without a word -

Why bother where I went? for I went spinning on the

four wheels of my car along the wet road until

I saw a girl with one leg over the rail of a balcony. 
tanta coisa depende

de um

carrinho de mão

vermelho

esmaltado de água de

chuva

ao lado das galinhas

brancas.

NO JOGO DE BEISEBOL

No jogo de beisebol a multida

é identicamente animada

por um espírito de inutilidade

que a delicia -

todo o detalhe emocionante

da perseguição

e da evasão, o erro

o lampejo de gênio -

tudo sem outro fim que nãa a belęa

o eterno -

Assim em detalhe os da multidato

são belos

por isso

o prevenir-se contra

o saudar e reptar -

Ela está viva, virulenta

sorri ferozmente

suas palavras cortam -

A moça vistosa ao lado

de sua mãe, entende isso -

82 so much depends

upon

a red wheel

barrow

glazed with rain

water

beside the white

chickens.

AT THE BALL GAME

The crowd at the ball game is moved uniformly

by a spirit of uselessness which delights them -

all the exciting detail of the chase

and the escape, the error the flash of genius -

all to no end save beauty the eternal -

So in detail they, the crawd, are beautiful

for this

to be warned against

saluted and defied -

It is alive, venomous

it smiles grimly

its words cut -

The flashy female with her mother, gets it -

estudos AVANÇADOS 
O judeu entende de imediato - ela

é mortífera, aterradora -

É a Inquisição, a

Revolução

É a própria beleza

que vive

dia por dia neles

ociosa -

Esse 0

poder do seus rostos -

É verão, é o solstício

a multidão está

gritando, a multidão está rindo em detalhe

permanentemente, gravemente

sem pensar

\section{A CABEÇA DE BACALHAU}

Miscelânea de algas

cordões, caules, detritos -

firmamento

de peixes -

onde as patas amarelas

das gaivotas chapinham

ramos batem

barcos deixam rastro de bolhas

- de noite doidamente

agitam-se fosfores-

centes animálculos - mas de dia

flácidas

luas em cujos

discos por vezes uma cruz vermelha

reside - quatro
The Jew gets is straight - it

is deadly, terrifying -

It is the Inquisition, the Revolution

It is beauty itself

that lives

day by day in them

idly -

This is

the power of their faces

It is summer, it is the solstice

the crowd is

cheering, the crowd is laughing

in detail

permanently, seriously without thought

\section{THE COD HEAD}

Miscellaneous weed strands, stems, debris firmament

to fishes where the yellow feet of gulls dabble

oars whip ships churn to bubbles at night wildly

agitate phosporescent midges - but by day flaccid

moons in whose discs sometimes a red cross lives - four 
braças - no fundo assenta

um salpico

de areias esverdeadas -

amorfo titu-

beio de rochas - três braças

o corpo

vítreo pelo qual -

peixinhos velozes descem

fundo - $e$

eis embalo um sobe

e desce -

estrelas vermelhas - uma decepada

cabeça de bacalhau entre

duas pedras - subindo

descendo. fathom - the bottom skids a mottle of green sands backward -

amorphous waver-

ing rocks - three fathom

the vitreous

body through which small scudding fish deep

down - and

now a lulling lift

and fall -

red stars - a severed cod -

head between two

green stones - lifting

falling.
POEMA

Ao trepar sobre

o tampo do

armário de conservas

o gato pôs

cuidadosamente

primeiro a pata

direita da frente

depois a de trás

dentro

do vaso

de flores

vazio.
POEM

As the cat climbed over the top of

the jamcloset first the right forefoot

carefully then the hind stepped down

into the pit of the empty flowerpot. 
AS ÁRVORES BOTTICELLIANAS

$\mathrm{O}$ alfabeto das árvores

val desmaiando na

canção das folhas

as hastes cortadas

das finas

letras que escreviam

inverno

e frio

foram iluminadas

com

pontas de verde

pela chuva e o sol -

As regras simples

e estritas dos ramos

retos

vão sendo alteradas

por ses de cor

pinçados, por cláusulas

devotas

os sorrisos de amor -

até as frases

desnudas

se moverem como braços

e pernas de mulher sob o tecido

e em sigilo o louvor

entoarem do desejo

e do império do amor

no estio -

No estio a canção

canta-se por si

acima das palavras surdas -
THE BOTTICELLIAN TREES

The alphabet of

the trees

is fading in the

song of the leaves

the crossing

bars of the thin

letters that spelled

winter

and the cold

have been illumined

with

pointed green

by the rain and sun -

The strict simple

principles of

straight branches

are being modified

by pinched-out

ifs of color, devout

conditions

the smiles of love -

until the stript

sentences

move as a woman's

limbs under cloth

and praise from secrecy

quick with desire

love's ascendancy

in summer -

In summer the song

sings itself

above the muffled words - 
A ACÁCIA-MELEIRA EM FLOR

Segunda versão

Por

entre

verde

velho

claro

rijo

roto

ramo

outro

branco

doce

Maio

vem .
THE LOCUST TREE IN FLOWER

Second version

Among

of

green

stiff

old

bright

broken

branch

come

white

sweet

May

again .

\section{O POEMA}

Tudo está

no som. Do som, a canção.

Mesmo rara. Bom

que seja uma canção - com pormenores, vespas,

uma genciana - algo

imediato, tesoura

aberta, olhos

de senhora - desperta,

centrífuga, centrípeta .

\section{A DURAÇÃo}

Uma folha amarfanhada

de papel pardo mais

ou menos do tamanho

e volume aparente

de um homem ia

devagar rua abaixo

86

\section{THE POEM}

It's all in

the sound. $A$ song.

Seldom a song. It should

be a song - made of particulars, wasps, a gentian - something immediate, open

scissors, a lady's eyes - waking centrifugal, centripetal .
THE TERM

A rumpled sheet of brown paper about the length

and apparent bulk of a man was rolling with the

estudos AVANÇADOS 
arrastada aos trancos

e barrancos pelo

vento quando

veio um carro e lhe

passou por cima

deixando-a aplastada

no chão. Mas diferente

de um homem ela se ergueu

de novo e lá se foi

com o vento aos trancos

e barrancos para ser

o mesmo que era antes.

\section{MULHER DIANTE DE UM BANCO}

O banco é uma questão de colunas, tal como . a convenção,

e não a invenção; mas os frontões

lá estão sob o sol

para acalmar as dúvidas

de investimentos "sólidos

como rocha" - sobre os quais o mundo

se firma, o mundo da finança,

o único mundo: Logo ali,

conversando com outra mulher enquanto

embala um carrinho de criança

de lá pra cá está uma mulher com um

vestido rosa de algodão, sem meias

nem chapéu; as pernas nuas

são duas colunas sustentando

seu rosto, como o de Lênin (o cabelo

frouxamente preso muito louro) ou

de Darwin, e aí

está:

mulher diante de um banco. wind slowly over

and over in

the street as

a car drove down

upon it and

crushed it to

the ground. Unlike

a man it rose

again rolling

with the wind over

and over to be as

it was before

The bank is a matter of columns, like . convention,

unlike invention; but the pediments sit there in the sun

to convince the doubting of investments "solid

as rock" - upon which the world stands, the world of finance,

the only word. Just there, talking with another woman while rocking a baby carriage

back and forth stands a woman in

a pink cotton dress, bare legged and headed whose legs are two columns to hold up her face, like Lenin's /her loosely

arranged hair profusely blond) or Darwin's and there you

have it.

a woman in front of a bank. 
O PARDAL

(A Meu Pai)
THE SPARROW

(To My Father)
Este pardal

que vem pousar em minha janela é uma verdade mais poética do que natural.

Sua voz, seus movimentos,

seus hábitos -

como gosta de

sacudir as asas

na poeira -

tudo 0 atesta; admito que o faça

para livrar-se de piolhos mas o alívio que experimenta leva-o

a gritar saudavelmente um traço que tem mais a ver com música

do que com outra coisa.

Onde quer que se encontre no início da primavera,

em becos obscuros

ou diante de palácios,

sem afetação ele logo se entrega

aos seus amores.

Tudo começa no ovo,

seu sexo o engendra:

Que haverá de mais pretensiosamente inútil

ou de que

tanto nos vangloriemos?

nossa perda.

Ele acarreta as mais das vezes

O galo novo, o corvo com

as suas vozes desafiadoras

não conseguem ultrapassar

a insistência

do seu pipilo!

Certa ocasião

em El Paso

ao cair da tarde,
This sparrow

who comes to sit at my window

is a poetic truth

more than a natural one.

His voice,

his habits -

his movements,

how he loves to

in the dust -

flutter his wings

all attest it;

granted, he does it

to rid himself of lice

but the relief he feels makes him

cry out lustily -

which is a trait

than otherwise.

Wherever he finds himself

in early spring,

on back streets

or beside palaces,

he carries on

unaffectedly

his amours.

his sex genders it:

It begins in the egg,

What is more pretentiously useless

or about which

we more pride ourselves?

to our undoing.

It leads as often as not

The cockerel, the crow with their challenging voices

cannot surpass

the insistance

Once

of his cheep!

at El Paso

toward evening,

estudos AVANÇADOS 
eu vi - e ouv! -

dez mil pardais

que tinham vindo do

deserto

empoleirar-se ali. Lotaram as árvores de um pequeno parque. As pessoas fugiram

(ouvidos a tinir!)

dos seus dejetos, deixando o local

entregue aos crocodilos

que viviam

na fonte. A imagem dele

é tão familiar

quanto a do unicórnio

aristocrático, e é pena

que não mais se coma aveia

hoje em dia

o que tornaria a vida

mais fácll para ele.

Nisso,

seus olhos penetrantes,

$$
\text { seu pequeno porte, }
$$

seu bico prestimoso

e sua agressividade

garante-lhe a sobrevivência -

para nada dizer

de suas inumeráveis

ninhadas.

Até os japoneses

o conhecem

e o têm pintado

empaticamente,

com profunda compreensão

de suas características

menores.

sequer remotamente

Nada de sutil

na sua corte amorosa.

diante da fêmea,

Ele se agacha

arrasta a asa,

a cabeça

valsando, e alça

é terrível.

e simplemente -

berra! $\mathrm{O}$ alarido

O modo como esfrega o bico numa prancha
I saw - and heard! -

ten thousand sparrows

who had come in from

the desert

to roost. They filled the trees

(with ears ringing!)

of a small park. Men fled

from their droppings,

leaving the premises

to the alligators

who inhabit

is familiar

the fountain. His image

as that of the aristocratic

unicorn, a pity

there are not more oats eaten

nowadays

to make living easier

for him.

At that

his small size,

keen eyes,

serviceable beak

assure his survival -

and general truculence

to say nothing

brood

of his innumerable

Even the Japanese

know him

and have painted him

sympathetically,

into his minor

with profound insight

characteristics.

subtle

Nothing even remotely

about his lovemaking.

before the female, He crouches

drags his wings,

throws back his head waltzing,

and simply -

is terrific.

yells! The din

The way he swipes his bill across a plank 
para limpá-1o,

é resoluto.

que faça. Seus supercílios acobreados

dão-lhe um ar

de ser sempre

um vencedor - no entanto

eu vi certa vez

uma fêmea da espécie, aferrando-se, decidida,

à beira de

um cano d'água,

agarrá-1o

pelas penas do cocontto

e mante-lo

calado,

subjugado,

suspenso sobre as ruas da cidade

até

ficar quites com ele.

Qual a utilidade

disso?

Ela ficou dependurada ali,

ela propria

admirada do seu feito.

Eu me ri com gosto.

Prático até o seu desfecho

é o poema

que triunfou

da existência dele

finalmente;

aplastado no calçamento, um punhado de penas

asas simetricamente abertas como que em vôo,

sem cabeça,

o negro escudo do peito indecifrável,

uma efígie de pardal

uma pasta seca apenas,

e o diz

dejxada ali para dizer

sem ofensa,

Isto era eu, lindamente;

um pardal.

adeus.

Fiz o melhor que pude; to clean it, is decisive.

he does. His coppery eyebrows

of being always give him the air

a winner - and yet I saw once,

the female of his species clinging determinedly to the edge of

a water pipe, catch him

to hold him

by his crown-feathers

silent,

subdued,

hanging above the city streets until

What was the use

of that?

herself,

she was through with him.

Practical to the end,

puzzled at her success.

She hung there

that triumphed

it is the poem

I laughed heartily.

of his existence

finally;

a wisp of feathers

flattened to the pavement, wings spread symmetrically

the head gone, as if in flight, the black escutcheon of the breast undecipherable,

an effigy of a sparrow, a dried wafer only,

and it says it left to say

without offense,

This was I, beautifully;

a sparrow.

farewell.

I did my best;

estudos AVANÇADOS 


\section{José Paulo Paes}

José Paulo Paes, 62, é paulısta de Taquarıtunga, poeta, ensaísta, crítıco literário, jornalista e editor, $\mathrm{c}$ um dos mass

importantes tradutores brasileiros de todos os tempos.

Intelectual de sólıda formação, pratıcamente autodıdata,

José Paulo Paes quase não possul títulos acadêmicos; sua obra literána, entretanto, inclut quase duas dezenas de livros de poemas, ensalos, crítica literária e antologias, cerca de quarenta traduçōes já publıcadas, mais de duas centenas de artigos em jornass e revistas nacionais e estrangeuras, além de intensa atıvidade editornal. De 1960 a 1982, for diretor editonal da Editora Cultrix (SP), é assessor da Bienal Nestlé de Literatura desde 1984 e membro da Comissão de Literatura da VITAE-Sociedade Cultural, Científica e Beneficente. Reconhecido por vános prêmios literários (APCA, Jabut, UBE), sua atıvidade como tradutor inclui o domínio do inglés, francês, italıano, grego moderno, alemão e espanhol. A presença fermentadora de José

Paulo Paes no IEA expressa uma dạs dirctrizes bástcas do Instituto: nenhuma exigência burocrática de tıtulação, observando-se, isto sim, o nível, necessariamente maximo, de seus professores-visitantes.

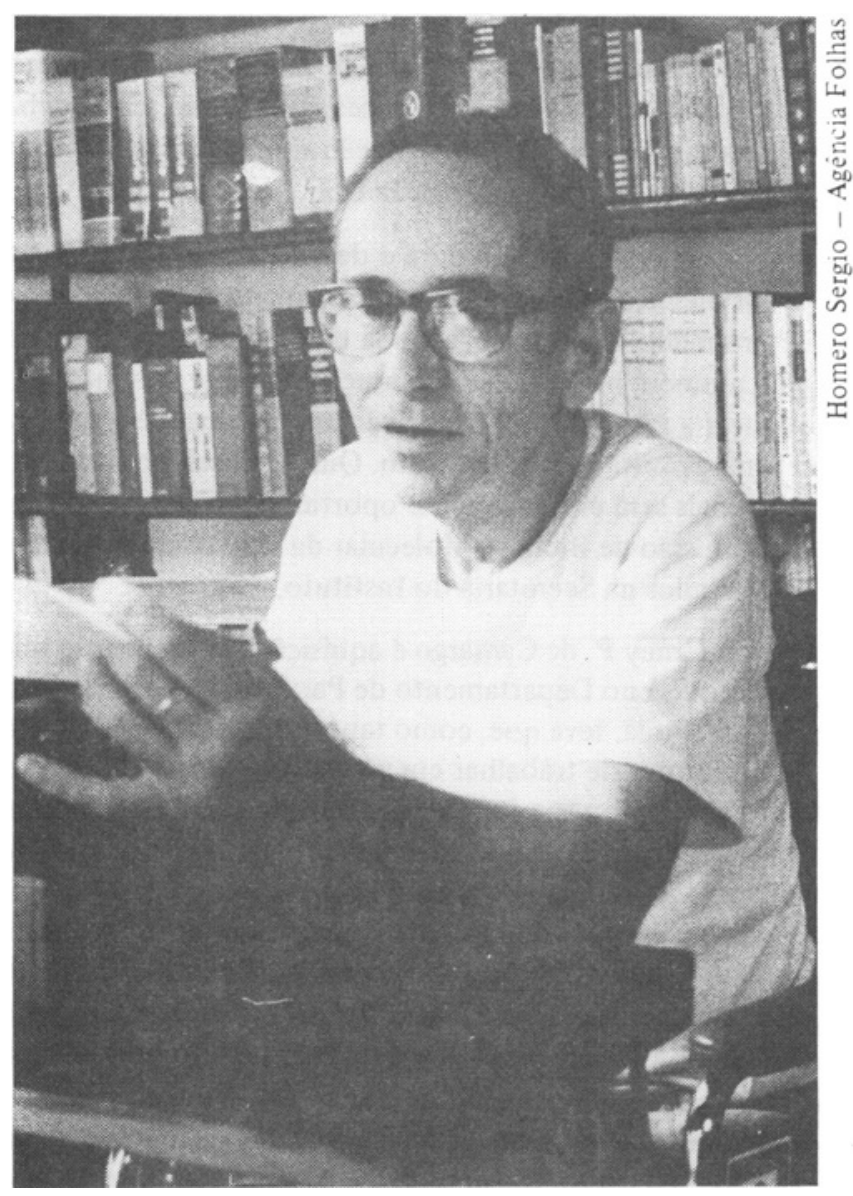

estudos AVANÇADOS 